\title{
ORIGEM DO MAL SEGUNDO SANTO AGOSTINHO: UMA PERSPECTIVA JUDAICO-CRISTÃ
}

\section{ARTIGO ORIGINAL}

CORSI, Uellinton Valentim ${ }^{1}$

CORSI, Uellinton Valentim. Origem do mal segundo Santo Agostinho: Uma perspectiva judaico-cristã. Revista Científica Multidisciplinar Núcleo do Conhecimento. Ano 05, Ed. 05, Vol. 01, pp. 131-152. Maio de 2020. ISSN: 2448-0959, Link de acesso: https://www.nucleodoconhecimento.com.br/filosofia/origem-do-mal

\section{RESUMO}

Este é um processo de pesquisa e hermenêutica sobre a origem do mal segundo Santo Agostinho em uma perspectiva judaico-cristã. O centro de interesse está presente nas obras do autor De Libero Arbitrio e Confessiones, que busca elucidar como é concebido o mal e sua origem e, como se dá o processo de construção interna no ser humano por meio do imperativo da vontade desvelado pelo autor.

Palavras-chave: Voluntas, Libero Arbitrio, Razão, Mal, Paixões.

\section{INTRODUÇÃO}

Responder a questionamentos que explicam a precedência do ser humano e o que 0 constitui como ente, é o que que muitos filósofos buscam por milênios. Santo Agostinho compõe este grande mosaico de pensadores. Deu sua colaboração na elucidação sobre a relação do ser humano com Deus e, o que será abordado neste artigo, a origem do mal.

Este estudo procura demonstrar, o paradoxo da voluntas e do libero arbitrio desde a origem de toda a criação, segundo a perspectiva judaico-cristã como artigo requerido

\footnotetext{
${ }^{1}$ Graduando de Filosofia na Pontifícia Universidade Católica do Rio Grande do Sul.
} 
à disciplina de Hermenêutica do curso de Filosofia e como pesquisa científica. Iniciando o estudo com o processo hermenêutico do relato da criação presente no livro do Gênesis, busca-se interpretar, com o auxílio de comentadores, todos os fatos contidos no capítulo primeiro deste livro que faz referência a criação, culminando na desobediência de Adão e Eva.

A dualidade do bem e do mal, razão e paixão e boa vontade e má vontade, perpassa todo o processo de pesquisa e hermenêutica aqui realizado. $O$ ser humano deseja fazer o bem, porém há algo em seu interior que, por vezes, não o permite fazer. Este algo, segundo Agostinho, deve vir antes mesmo da decisão de fazer ou não alguma coisa. Seria como um algo metafísico que ele denomina como Libero Arbitrio. Ele é causa sui, autodeterminante, que tende a cometer uma boa ou má ação.

É um paradoxo da humanidade de cada ser humano. Como superar esta, de certa maneira, inclinação para o mal, que como afirma São Paulo "Não faço o bem que quero, mas o mal que não quero"? A elucidação desta problemática será buscada ao decorrer deste estudo, porém não se chegará a uma resposta definitiva. Será oferecido meios para a construção de interpretações sobre esta temática e, com isso, não finda o artigo com o seu fim, mas permite continuar a pesquisa futuramente.

\section{ORIGEM DO MAL SEGUNDO SANTO AGOSTINHO}

\subsection{O MAL NUMA PERSPECTIVA JUDAICO-CRISTÃ}

Durante séculos o homem pergunta o que move o espírito humano a escolher uma boa ou má ação e quais os critérios para efetuar tal escolha. Esses questionamentos procuram, inicialmente, compreender a origem do homem e do que consiste em sua essência. Filósofos de importância para a filosofia ocidental, como Santo Agostinho, procuram dar essa resposta observando o que seus predecessores propuseram concatenando com suas reflexões, que eram novas, para tentar resolver o paradoxo. Fazendo um retorno na história, observa-se que a escolha entre o bem e o mal faz parte desde os primórdios da humanidade, ou pelo menos, o que se compreende 
como início, segundo determinada tradição religiosa, o judaísmo e posteriormente o cristianismo.

O povo hebreu, conhecido como Judeu ou Israelita, procura explicar o surgimento do mal desde a fundamentação de sua crença. Encontra-se, segundo esta ótica, a dimensão originária do mal no livro do Gênesis, que é o primeiro livro do Pentateuco[2]. Este livro têm a narrativa da criação do mundo e, por consequência, da criação do Homem e da Mulher:

[...] 9.0 Senhor Deus fez brotar da terra toda a sorte de árvores de aspecto agradável, e de frutos bons para comer; e a árvore da vida no meio do jardim, e a árvore da ciência do bem e do mal. 15.0 Senhor Deus tomou o homem e o colocou no jardim do Éden, para cultivar o solo e o guardar. 16.Deu-Ihe este preceito: "Podes comer do fruto de todas as árvores do jardim; 17.mas não comas do fruto da árvore da ciência do bem e do mal; porque no dia em que dele comeres, morrerás indubitavelmente [...] 21.Então, o Senhor Deus mandou ao homem um profundo sono; e enquanto ele dormia, tomou-Ihe uma costela e fechou com carne o seu lugar. 22.E da costela que tinha tomado do homem, o Senhor Deus fez uma mulher, e levou-a para junto do homem. 23."Eis agora aqui - disse o homem - o osso de meus ossos e a carne de minha carne; ela se chamará mulher, porque foi tomada do homem [...] 25.0 homem e a mulher estavam nus, e não se envergonhavam [...] (Gn 2, 9 , $15-17,21-23,25)[3]$.

Como é possível observar, para os judeus, Deus é o Criador de todas as coisas, inclusive do Homem e da Mulher, sendo esta retirada da costela do Homem. Ele também criou a árvore que contém a ciência do bem e do mal e dá ordens estritas para que não seja comido de seu fruto, pois resultaria na morte do ser humano[4].

A narrativa continua o relato da criação e dos preceitos dados à Adão e Eva por Deus. Tudo estava perfeitamente ordenado, havia harmonia entre criador e criatura. Até o surgimento de uma serpente que conduz - fornece informações a - Eva ao erro: 
1.A serpente era o mais astuto de todos os animais do campo que o Senhor Deus tinha formado. Ela disse à mulher: "É verdade que Deus vos proibiu comer do fruto de toda árvore do jardim?" 2. A mulher respondeu-Ihe: "Podemos comer do fruto das árvores do jardim. 3. Mas do fruto da árvore que está no meio do jardim, Deus disse: 'Vós não comereis dele, nem o tocareis, para que não morrais'. 4."Oh, não! - tornou a serpente - vós não morrereis! 5.Mas Deus bem sabe que, no dia em que dele comerdes, vossos olhos se abrirão, e sereis como deuses, conhecedores do bem e do mal." 6.A mulher, vendo que o fruto da árvore era bom para comer, de agradável aspecto e muito apropriado para abrir a inteligência, tomou dele, comeu, e o apresentou também ao seu marido, que comeu igualmente. 7.Então os seus olhos abriram-se; e, vendo que estavam nus, tomaram folhas de figueira, ligaram-nas e fizeram tangas para si. 8. E eis que ouviram o barulho (dos passos) do Senhor Deus que passeava no jardim, à hora da brisa da tarde. O homem e sua mulher esconderam-se da face do Senhor Deus, no meio das árvores do jardim [...] (Gn 3, 1-8)[5].

Impressionante constatar a passagem da ordem em que se encontrava Adão e Eva à desordem, dado o motivo da serpente "induzir" a mulher a desobedecer a um preceito dado por Deus. Após Eva comer do fruto da árvore da ciência do bem e do mal e oferecer ao seu marido, o autor narra que os seus olhos abriram e perceberam que estavam nus. Acontece aqui a passagem direta da vida para a morte, pois começam a dar-se conta da sua condição humana de finitude e envergonhar-se. É mister salientar que para além da presença da serpente que "induz" Eva a comer do fruto proibido, a mulher faz as observações necessárias para tomar a decisão[6]. Isso o autor narra, claro e distintamente, ao dizer que ela "tomou dele, comeu e apresentou também ao seu marido, que comeu igualmente" (Gn 3,6). É exatamente neste instante que se contempla a mulher e o homem fazendo uma escolha, e esta é pautada pela vontade que os conduz ao erro, ou como o autor relata, à morte[7]. 
A morte aqui deve ser compreendida não como morte física, mas sim como ausência do unicamente bem e presença do erro, expulsão do Éden e, principalmente, o rompimento da solidariedade original entre criatura e Criador, que foi a consequência do ato de Adão e Eva, assim afirma Lopez:

[...] Antes da tentação e da queda, o narrador havia observado que "o homem e a mulher estavam nus, mas não se envergonhavam" $(2,25)$. Depois da queda observa-se que "tomaram folhas da figueira, entrelaçaram-nas e fizeram cinturas para si", ao verem que estavam nus $(3,7)$. Indica-se, deste modo, o primeiro desequilíbrio: a vergonha como consequência da queda. É o sentido profundo da culpa experimentada pelos seres humanos. No diálogo de Deus com o primeiro casal humano e nas maldições sucessivas, surgem outros desequilíbrios: o medo $(3,10)$, a dor e a angústia (3,16), o cansaço (3,17-19). Rompe-se a solidariedade original entre o homem e a mulher; quebra-se igualmente a solidariedade original entre o homem e a terra. E o que é ainda pior: o pecado rompe a solidariedade original entre criatura e Criador [...][8].

Constata-se, segundo o autor, breve elucidação cronológica, diga-se assim, dos fatos sucessivos a desobediência de Adão e Eva. Percebe-se que essa desobediência motivada pela vontade de Eva em escolher comer o fruto, revela a íntima relação do desejo de ser deus e possuir o conhecimento do bem e do mal[9], mesmo que isso resulte na sua morte, sendo esta, consequência da vontade de tomar a decisão de desobedecer ao mandato divino. Assim, segundo a tradição judaico-cristã, surgiu o mal ou o pecado original e, desde então, o ser humano está quase fadado a cometer o mal mesmo querendo fazer o bem, como diz São Paulo em sua carta aos Romanos "Não faço o bem que quero, mas o mal que não quero"[10].

É necessário, ainda, romper com a tradição interpretativa que pode cometer o erro de colocar em Deus a culpa de criar o ser humano imperfeito, permitindo a este ser a capacidade de cometer o mal[11]. Também essa interpretação pode levar a condição da mulher como um simples instrumento do pecado. Precisa ser levado em consideração que este mito foi constituído para dar resposta aos questionamentos - 
quanto a existência humana - do povo da época em que foi escrito e isso já exerce muita influência sobre o redator. Assim é destacado na Bíblia Sagrada Ave Maria, versão de estudos (São Paulo: Editora Ave Maria, 2019. Nota p. 24) "Na Bíblia, esses mitos sofrem uma mudança de referencial, uma adaptação necessária para transmitir a verdade que os sábios querem anunciar a seu povo". Observa-se que o pano de fundo da passagem da Criação, é o questionamento do povo hebreu quanto a existência humana e, na tentativa de responder à luz da fé, os sábios e patriarcas produziram esta bela composição textual. Para os crentes, mesmo tendo sido escrita por mãos humanas, há aí a inspiração divina elucidando a origem humana e sua essência[12].

A atenção central nesse relato, não deve permanecer na serpente que "induz" a mulher ao erro e na mulher que o comete, mas sim na "árvore da ciência do bem e do mal" (Gn 2, 9) que seduz tanto Eva quanto Adão a comer de seu fruto, como afirma a Bíblia Sagrada (São Paulo: Editora Ave Maria, 2019. Nota pp. 24-25) “A sedução tampouco provém da mulher, e sim do fruto que 'era bom para comer, de agradável aspecto e muito apropriado para abrir a inteligência' (v.6)”. Assim, constata-se que há vários aspectos importantes, sem dúvida, mas a hermenêutica que se realiza aqui, não quer mostrar a sedução da mulher que leva o homem ao erro, tão pouco quer afirmar que o ser humano é um ser inocente ou que há algo sexual envolto na narrativa, mas sim o quão profundo é no ser humano se utilizar como medida para a escolha entre o bem e o mal. Tentativa falha, pois sabe-se que para tomar qualquer decisão, o ente sofre influências externas e internas, o que pode colaborar para conduzi-lo ao erro ou ao acerto.

Um tanto quanto questionada é a interpretação errônea feita durante séculos sobre esta passagem do Antigo Testamento, onde, de certa forma, retira do ser humano a responsabilidade de suas escolhas, dando a ele um subterfúgio para a expiação de sua culpa. Porém, atualmente, se sabe que o ser é responsável pelos seus atos a não ser que ele tenha algum desequilíbrio psíquico que o torne incapaz de tomar qualquer decisão. Portanto, o ser humano tem a oportunidade de tomar consciência de sua finitude e reconhecer, com muita humildade[13], suas limitações, não procurando 
culpabilizar outrem por seus atos. Dado o exposto, é importante fazer correta interpretação dos escritos de acordo com o seu tempo pois, textos quando interpretados fora de seu contexto, tornam-se apenas pretextos justificativos.

Portanto, Adão e Eva ao comer do fruto da árvore da qual Deus havia proibido, são responsabilizados pelo ato cometido[14]. Isso demonstra que o grande erro não foi ter comido o fruto, mas sim ter se colocado como medida única de todas as coisas, elevando seu interesse próprio acima do bem maior, como uma norma suprema, não obedecendo a lei eterna[15] da qual a moralidade é fundamentada. Na práxis, isso acontece atualmente quando o ser humano se toma como medida normativa para seus atos, não levando em consideração a vida do seu semelhante, resultando na dizimação de povos e na prática de injustiças impiedosas.

Contudo, se levanta o paradoxo da vontade[16], onde se percebe que mesmo desejando fazer o bem, o ser, por vezes, falha na tentativa e acaba cometendo o mal não querido. Santo Agostinho em seu livro De Libero Arbitrio[17] faz um tratado sobre a origem do mal e, durante o diálogo com Evódio[18], procura elucidar esse mistério humano. O diálogo tende fundamentar como o ser humano, em sua liberdade, opta em cometer o mal e deixa de fazer o bem.

\subsection{AGOSTINHO E A ORIGEM DO MAL}

Como visto, a vontade do ser humano é que determina sua escolha em fazer o bem ou mal. É complexo compreender que o homem, sendo criatura de Deus e contendo o sopro de vida, logo, o Espírito, não consegue exercer a asserção benéfica de seus atos. Parte-se da premissa de que Deus é perfeito e bom, e por assim ser, o que cria também possui categoria de perfeição e benevolência. À vista disso, tomar como verdade que Deus criou o ser com imperfeições e com o mal, é contradizer o preceito de perfeição e bondade, além disso, o conceito de justiça também é atribuído a Deus, pois Ele distribui recompensa aos bons e castigo aos maus, cada um recebe de acordo com sua prática. 
Porém, se não foi Deus quem criou e cometeu o mal por primeiro e não criou seres imperfeitos, quem foi seu autor? Agostinho alega em "O Livre Arbítrio" (São Paulo: Paulus editora, 2019. p. 26 - 27) que "O mal não poderia ser cometido sem ter algum autor. Mas caso me perguntes quem seja o autor, não o saberia dizer. Com efeito, não existe um só e único autor. Pois cada pessoa ao cometê-lo é o autor de sua má ação." Ou seja, cada ser humano procede de acordo com sua vontade, sendo ela boa ou má, e é responsável pelos seus atos e punido por eles, seja pela lei temporal ou eterna. Caso as ações não fossem de responsabilidade humana e voluntariamente realizadas, o ser humano não poderia receber a recompensa bem como a punição, mas o faz.

O ser é dotado de sabedoria, e esta é o resultado do senhorio do entendimento sobre as paixões, em vista disso, encontra-se em Platão a afirmação que as paixões levam o ser humano ao erro e que a razão deve ser primaz sobre as paixões[19]. O desejo desordenado também pode conduzir a pessoa ao mesmo resultado. Ambas as dimensões internas dos seres humanos, devem ser domesticadas ("mansueti") pela razão ("ratio"), sendo esta intimamente ligada com o Logos Criador que contém toda a sabedoria e conhece tudo, e o todo conhecido é puramente verdade, alega Boécio:

Aquele que apreende e possui de uma só vez a totalidade da plenitude de uma vida sem limites, à qual não falta nada do futuro nem nada escapa do passado, esse sim pode ser considerado com razão como um ser eterno, e é necessário que ele esteja sempre presente e em plena posse de si mesmo, já que para ele o presente abarca todo o tempo ilimitado[20].

Ele busca resolver o mistério sobre a eternidade de Deus e de sua onisciência. Para o Ente divino que tudo sabe e conhece, o presente é um eterno agora, simplesmente é. Nada escapa de seu conhecimento e este conhecimento não determina a ação humana, não retira do ser humano aquilo que Ihe é genuíno, a liberdade de suas ações. Por assim dizer, Deus que criou tudo e todos, deixou seu Espírito no homem ao dar-Ihe o sopro de vida, como precede na passagem da criação. Por possuir o sopro divino como anima (que dá vida e movimento aos seres) eles participam, em 
certa medida, da essência divina e, por consequência, da eternidade. O ente humano, então, é possuidor de intelecto e tem a faculdade da razão que deve orientar suas escolhas e estas orientá-los em direção ao seu Criador.

Parece contraditório que um ser que tem potencialidade extraordinária de entendimento, e que participa da existência divina por meio da razão e da anima, não consiga a primazia da razão sobre seus instintos primitivos e desordenados, que são efeitos da paixão pelas coisas temporais e vis. Indagações como estas estão presentes em Agostinho:

É possível que o entendimento não exerça o seu senhorio num ser humano particular. A pergunta simples, mas que parece ter inquietado Agostinho sobremaneira, é a seguinte: como é possível que o entendimento não domine os desejos? Agostinho, assim, dá novo conteúdo à mesma pergunta que fora colocada no início da investigação. Dado que o senhorio das afecções irracionais da alma sobre 0 entendimento é o quod - a definição - da má ação moral e, ao menos num sentido elementar, a causa mesma da má ação, a pergunta pela origem do mal precisa ser repetida: unde male faciamus?[21].

Percebe-se que o ente humano mesmo sendo possuidor de razão e sabedoria, é passível de realizar má ação pela desordem irracional da alma, quando esta exerce primazia sobre o entendimento.

Assim, a vontade é presente na tomada de decisão que os seres humanos fazem e ela, por sua vez, quando desordenada, permite a primazia do desejo de possuir a ciência do que é bom e mal, de colocar-se no lugar de Deus e ter a si como referência para tomar qualquer decisão. Porém, como saber se tal ação é boa ou má? Pelo fato que se for má não quereria ser feita para si, caso for bem, quereria. É preciso ainda distinguir o mal pessoal do coletivo. Não se pode condenar um pelo mal cometido pelo outro e nem tomar a condenação na lei temporal como algo completamente justo, pois se assim o fizer, tantos mártires e até mesmo Jesus Cristo teriam sido condenados justamente. Há necessidade de servir à lei eterna, se o faz, garante, por ora, proceder 
de acordo com a lei temporal, a não ser que esta, ao ser criada, tenha sido corrompida pelo seu legislador[22].

O proceder mal, em suas mais variadas formas, é reflexo da paixão interior. Esta paixão, juntamente com o desejo, faz o ser apegar-se em bens, coisas e pessoas temporais e ter medo de os perder. Tendo medo de que isso aconteça, ele fará de tudo para garantir que seus bens não o sejam tirados. O temor faz com que ele cometa das mais variadas ações em prol de algo que não quer perder. Analogamente, o homem que deseja viver sem medo visa um bem, mas esse desejo não é exclusivo de homens bons, mas também dos maus, por isso, não é possível generalizar e validar toda e qualquer busca para garantir esse viver sem medo, afirma Santo Agostinho:

Desejar viver sem temor, não só é próprio de homens bons, como também dos maus. Com esta diferença, porém: os bons o desejam renunciando ao amor daquelas coisas que não se podem possuir sem perigo de perdê-las. Os maus, ao contrário, desejam uma vida sem temor, para gozar plena e seguramente de tais coisas, e para isso esforçam-se de qualquer modo para afastar todos os obstáculos que o impeçam. Levam então vida criminosa e perversa - vida que deveria antes ser chamada de morte[23].

É possível reconhecer que há vontade boa com finalidade para o bem e vontade boa com finalidade para o mal. Consequentemente, é imprescindível averiguar minuciosamente qual o desejo que está movendo o ser humano a cometer tal ação e para que fim direciona sua razão e sabedoria, pois como mencionado, o ser humano desordenado interiormente tende a permitir a primazia da paixão sobre o entendimento, tornando-se escravo dos vícios que desvirtuam a alma, que é o bem mais precioso da pessoa humana.

\subsection{LIBERO ARBITRIO ET VOLUNTAS[24]}

Ao expor e analisar os argumentos precedentes, percebe-se que há um paradoxo onde o ser humano procura fazer o bem e viver virtuosamente, porém, por vezes, não 
consegue. O que leva, então, o ser a não conseguir realizar seu desejo de querer proceder bem? Para tentar resolver esse paradoxo, Agostinho formula a existência de uma potência distinta do desejo e do entendimento, que é a livre vontade[25]. Além disso, procura expor diretamente sobre a razão em contraponto com a paixão, o intelecto ao desejo, como menciona Roberto Pich:

Premissa importante para a formulação do paradoxo é a ideia decididamente assumida por Agostinho de que o intelecto é "mais poderoso" ("potentior") que a paixão ("libido"). E, do fato mesmo de o intelecto ser mais poderoso que o desejo ("cupiditas"), é também justo que ele domine o desejo[26].

Confirmando o afirmado, Agostinho fala diretamente da lei eterna:

Julgas que a paixão seja mais poderosa do que a mente, à qual sabemos que por lei eterna foi-Ihe dado o domínio sobre todas as paixões? Quanto a mim, não o creio de modo algum, pois, caso o fosse, seria a negação daquela ordem muito perfeita de que o mais forte mande no menos forte. Por isso, é necessário, a meu entender, que a mente seja mais poderosa do que a paixão e pelo fato mesmo será totalmente justo e correto que a mente a domine[27].

Sendo assim, é um preceito natural e eterno de que o que é mais forte domine o mais fraco, então o mesmo deve acontece entre a mente e a paixão. A mente, por ser mais forte, deve dominar os impulsos motivados pela paixão, mas o enigma[28], como mencionado, é justamente que muitas vezes o contrário acontece[29]. E como tentativa de resolução, Agostinho procura algo que prescinda a mente, o intelecto, os desejos e até a paixão, algo, de certa forma, metafísico, que vem antes de o ser humano decidir.

Esse algo metafísico é denominado pelo autor como livre arbítrio ou vontade livre. Para Agostinho, é essa potencialidade presente em todo ser humano que decide o seu agir moral ou imoral. Na sua obra O Livre Arbítrio (São Paulo: Paulus editora, 
2019. p.50) diz que "Não há nenhuma outra realidade que torne a mente cúmplice da paixão a não ser a própria vontade e o livre-arbítrio". Aqui está o ponto crucial onde o autor revela, após constatar todas as formas possíveis que poderiam condicionar o ser humano a cometer o pecado, que somente a vontade e o livre-arbítrio pode tornar o ser cúmplice, e até escravo, de suas paixões, e permitir que estas condicionem suas ações e o conduzam ao erro. Há, por assim dizer, inclinação no ser humano para, por vontade livre, fazer opção pelo mal e não pelo bem. A liberdade é uma propriedade da vontade, torna-se um arbítrio livre, uma decisão soberana, o agir como se quer e senhor dos atos, sejam eles bons ou maus[30].

Como exposto, a vontade livre tende tanto para o ato bom quanto para o mau, por isso o ser humano pode procurar realizar ações boas que o torne feliz. Santo Agostinho determina estas ações como sendo consequência da Boa Vontade[31], (São Paulo: Paulus editora, 2019): "É a vontade pela qual desejamos viver com retidão e honestidade, para atingirmos o cume da sabedoria". E ainda: "Portanto, penso que agora já vês: depende de nossa vontade gozarmos ou sermos privados de tão grande e verdadeiro bem". Esta dualidade presente no ser humano é o que o torna livre para fazer escolhas, pois, caso não houvesse tais possibilidades ele seria condicionado a viver unicamente para o bem ou para o mal e, por consequência, não seria livre. Por isso, no início desse artigo, foi apresentada a passagem bíblica da criação contida no livro do Gênesis, pois mostra de maneira clara que o ser humano tem livre vontade para fazer suas próprias escolhas, tanto para o acerto como para o erro. É imprescindível recorrer a fontes, tais como a de Gênesis, para compreender a dimensão religiosa de um povo, uma tradição e, principalmente, do que está no inconsciente coletivo de grande parte da humanidade. Também para evitar fundamentalismo e interpretações errôneas, deslocando a culpa do ser humano para o seu Criador.

Faz-se mister reconhecer a livre vontade que os primeiros seres criados por Deus possuem. Ao desobedecer ao preceito divino cometem um ato por vontade livre, mesmo sofrendo influência da serpente, e foram condenados por isso. Como visto anteriormente, há um preceito de justiça tanto eterna quanto temporal que dá ao bom 
as recompensas e ao mau a punição tendo por base as ações cometidas[32]. Este preceito de justiça é apresentado de maneira direta na passagem da criação quando Deus expulsa Adão e Eva do Éden:

O Senhor Deus fez para Adão e sua mulher umas vestes de peles, e os vestiu. E o Senhor Deus disse: "Eis que o homem se tornou como um de nós, conhecedor do bem e do mal. Agora, pois, cuidemos que ele não estenda a sua mão e tome também do fruto da árvore da vida, e o coma, e viva eternamente. O Senhor Deus expulsou-o do jardim do Éden, para que ele cultivasse a terra "de onde havia tirado". E expulsou-o[33].

O Criador não negou sua criação, mas deu-lhes o que era justo pelos atos cometidos. O homem e a mulher, com a desobediência originária, tornam-se seres autônomos, senhores de suas vontades, o que pode levá-los para a felicidade eterna ou ao perecimento no vício e pecado.

\subsection{VIRTUS ET BEATITUDINEM[34]}

Levar uma vida virtuosa, para Agostinho, consiste na busca pela felicidade[35]. Ele não impõe impossibilidade de isso acontecer, pelo contrário, afirma que o ser humano, possuidor de boa vontade, deseja a felicidade como finalidade de seus atos, porém, para que isso aconteça há deveres a serem observados:

Como se explica que os homens sofram voluntariamente uma vida infeliz, se de modo algum ninguém quer viver infortúnio? $\mathrm{E}$ como se explica que, sendo por sua própria vontade que o homem obtém vida feliz, quando acontece que tantos são infelizes, apesar de todos quererem ser felizes? Será que isso não vem do fato de que uma coisa é querer viver bem ou mal e outra coisa muito distinta é merecer o resultado por uma boa ou má ação? Com efeito, aqueles que são felizes - para isso é preciso que sejam também bons - não se tornaram tais só por terem querido viver vida feliz - visto que os maus também o querem. Mas sim, porque os justos o quiseram com retitude, o que os maus não 
o quiseram. Nada de estranhar, então, que os homens desventurados não obtenham o que querem, isto é, vida feliz[36].

Existe uma constante duplicidade no ser humano e em suas escolhas. Agostinho afirma claramente que para buscar a felicidade não basta a vontade, mas sim a boa vontade, e esta consiste no agir bem do ser humano. A felicidade é a recompensa dos bons, que tem ações boas e que procuram viver uma vida com retidão, virtuosa, coisa que muitos não conseguem, porque exige renúncia de seus desejos e paixões. Resultado disso, é que tanto o bom quanto o mau almejam a felicidade, porém ela se dá para o que age bem e para o outro ela é um eterno vir a ser.

Essa exigência para alcançar a felicidade, elabora uma categoria entre os seres humanos, entre os que conseguem, por vontade livre e boa vontade realizar boas ações e, por meio destas, alcançar a felicidade; e outros que tem a vontade livre e acabam escolhendo viver segundo as paixões e os desejos e não deixam de amar as coisas temporais, não conseguindo assim, viver uma vida de retidão e virtuosa[37]:

O essencial, o que acompanha a felicidade e sem o que ninguém é digno de obtê-la - o fato de viver retamente -, eles não querem. Ora, a lei eterna, em consideração da qual já é tempo de voltar a nossa atenção, decretou com firmeza irremovível o seguinte: o merecimento está na vontade. Assim, a recompensa ou o castigo: a beatitude ou a desventura[38].

Mais uma vez, a justiça está presente para julgar segundo as ações cometidas pela vontade livre de cada ser humano. Agostinho não afirma um determinismo ao erro, mas sim que existem pessoas que são mais capazes de viver ou procurar viver uma vida virtuosa que outras. Isso, porém, não coloca as que não conseguem em uma fatídica condenação, mas abre a possibilidade de o ser humano assumir com muita humildade suas limitações, como citato acima, e pedir o auxílio de seu Criador para alcançar a beatitude eterna. 
Partindo da premissa que a relação entre criatura e Criador é interna e silenciosa, ela possibilita que o ser, no mais íntimo de si, mostre para o Summum Bonum[39] quem realmente é e quais suas reais necessidades. Este princípio, por ser uma relação interna e pessoal com o Criador e, acreditando na Omniscientia (Onisciência), se supõe que, Ele que tudo vê e tudo sabe, também conhece o interior humano[40], como diz o Salmo (132, 1-2) "Senhor, tu me sondas e me conheces. Sabes quando me sento e quando me levanto; de longe percebes os meus pensamentos". O que possibilitaria tamanha ligação com o Summum Bonum? Para alcançar a resposta de profunda inquirição, faz-se necessário buscar algo que difere o ser humano dos outros animais. Para tal, elimina-se a hipótese de ser as sensações e a animação do corpo, pois estas propriedades também estão presentes no animal.

O que, então, diferencia o animal e o ser? O pensar, ter consciência de que está vivo, saber que ocupa um tempo e espaço e que possui sentimentos. Que faculdade tão nobre seria esta, se não a alma que, partícipe do Uno Criador, está presente nEle e Ele nela?[41] afirma Jorge Machado:

'Eu devo ir além dos meus poderes de animação e sensação, que os animais também possuem, para encontrar Deus'. Para Agostinho, quem dirige o caminho para Deus é a minha própria alma, é o "interior humano". Portanto, eu assim venho para o "depósito oculto" e "infinito" da memória[42].

Portanto, é preciso ir além do comum aos seres animados e ter a percepção de algo que está dentro de cada ser humano, e que permite que ele perceba o quão misterioso ele é para si. Esse mistério pode levá-lo à um grande silêncio interior quando, confrontado consigo e com sua finitude, reconhece que é necessitado de Deus para que possa atualizar todas as potencialidades intrínsecas em si.

Interessante observar, que essa busca lança o ser para a autopercepção o que, à medida que aprofunda seu saber sobre si, vai alcançando certa tranquilidade interior, pois conhecer a si é o princípio básico que a psicologia moderna afirma como harmonia de ser[43]. Tal busca, favorece à pessoa está harmoniosa vivência, mas 
para além disto, o caminho foi traçado para encontrar Deus e isso se dá por intermédio da incessante busca de ser feliz[44] do ser humano, como afirma Jorge Machado (Porto Alegre, 2006) “'Quando eu procuro Tu, meu Deus, eu procuro uma vida feliz. Eu te procuro para que minha alma possa viver'. O que me guia em minha busca é, assim, a angústia, o interesse por minha própria vida, para que essa seja verdadeiramente vivida[45]". Instaura-se, assim, o mistério do conhecer-se e do conhecer a Deus, o que pode gerar controvérsias nesta compreensão. Agostinho, inquieto por esses questionamentos, não cansa em tentar conhecer essa verdadeira Verdade ("Veritas”). É possível conceber que a vida feliz ou a felicidade está intimamente ligada com a existência de Deus, pois se há verdadeira felicidade, esta fundamenta-se em uma felicidade eterna, ligada ao conhecimento e este a Verdade.

Ela, assim dizendo, está no possuir a sabedoria, logo, a verdade, e esta é o Sumo Bem[46]. Quem possui a sabedoria - verdade - consequentemente possui a Verdade Eterna, ou como denominado pelo autor, o Bem, e quem desiste de buscá-la, erra levando vida infeliz pois afasta-se do Bem e, logo, da verdade que vai exprimir sentido a sua existência:

Na medida, pois, em que todos os homens desejam a vida feliz, não erram. Mas na medida em que alguém abandona o caminho da vida que leva à beatitude, mesmo quando declara e proclama não querer senão chegar até à beatitude, nessa mesma medida erra. Com efeito, há erro quando seguimos um caminho que não pode nos conduzir aonde pretendemos chegar. E quanto mais uma pessoa erra no caminho da vida, menos ela é sábia, porque tanto mais afasta-se da verdade, na qual se contempla e se possui o Bem supremo. Ora, uma vez alcançado o Sumo Bem, cada um torna-se feliz, o que sem contestação todos nós queremos[47].

Dessa forma, quanto mais o ser humano procura levar uma vida virtuosa, com retidão e observa a lei eterna[48], mais se torna sábio e se aproxima da verdade, e esta consiste no Sumo Bem. Então, qual a finalidade da existência humana senão buscar a perfeita ordem instaurada desde o início de tudo, que por uma desobediência 
afastou a todos deste Bem tão querido? Todos possuem intrínseco desejo de busca pelo conhecimento e, essa busca conduz à verdade e, esta é a Origem de tudo. Este movimento leva o ser humano a um perfeito ordenamento com relação ao seu Criador, a si e a toda a criação.[49]

Porém, como Dionísio afirma (Obras Completas del Pseudo Dionisio Areopagita. Madrid: Biblioteca de Autores Cristianos, 1990) "as nomenclaturas usadas para tentar exprimir o que ou quem é Deus são limitadas". Ao tentar conceituar Deus, encontrase o limite do dizível do que realmente é. Por isso, Deus é indizível e ao tentar conhecer a verdade de quem é Deus, chega-se a um grande silêncio contemplativo, pois diante da grandiosidade do Mistério, cessam todas as palavras e permanece apenas o espírito a contemplar seu Criador. Dionísio continua a afirmar:

Por isso, como norma geral, nada se atreverá falar da Divindade supra essência e secreta em terminologias e ideias que não foram divinamente reveladas nas Sagradas Escrituras. Efetivamente, qualquer palavra e conceito são inadequados para expressar o desconhecido da supra essência, que está muito acima de todo ser. Transcende toda razão, toda intuição, todo nome. Ele é o Ser e nenhum ser é como Ele. Causa de tudo o que existe. Ele está fora das categorias do ser. Somente Ele, com sua sabedoria e senhorio, pode dar a conhecer de si mesmo a quem quer[50].

Essa divindade se torna conhecida, unicamente, quando decide se revelar aos seres humanos. A pessoa precisa confiar e pedir Seu auxílio para ultrapassar as limitações que se encontram na vontade e livre-arbítrio e que conduz o ser ao erro[51]. A este Ser, envolto em mistério e sábio, que por séculos se busca alguma definição e, em uma tentativa vã, se tenta objetivar, precisa, em uma atitude de confiança, se abandonar e crer na sua Providência, pois como afirma Dionísio, Ele se dá a revelar a quem ele quer e no tempo que achar preciso, pois está em um eterno presente e tudo para ele é. 
O Ser Supremo, que Agostinho denomina de Sumo Bem, na figura de seu Filho Jesus Cristo, coloca-se próximo de todas as pessoas para ouvir suas petições. Permanece a altura dos seres humanos para perscrutar os recônditos de cada um, pois sabe o quão limitados os são e que precisam de auxílio para alcançar a perfeição possível, como diz o evangelista Mateus $(7,8)$ "Pedi e vos será dado. Buscais e achareis. Batei e vos será aberto. Porque todo aquele que pede, recebe. Quem busca, acha. A quem bate, se abrirá."

Logo, cumpre-se um preceito dado para a humanidade, quando, em um ato de humildade e misericórdia consigo mesmo, o ser humano reconhece sua finitude que tende ao vício e permanecer ao jugo das paixões, onde a razão não as conduzem, e pede a ajuda do Sumo e Eterno Bem. Esse é o caminho que conduz à sabedoria e está ao alcance de todos, porém é necessário esforço para iniciar essa busca. É plausível, por mais uma vez, retornar ao relato da Criação e observar que mesmo quando Deus expulsa Adão e Eva do Éden ele provê roupas e terras para eles. Ambos, desobedeceram a Deus, mas Ele não deixou de ter misericórdia para com sua imagem e semelhança, que é o ser humano. Portanto, é evidente que o ser humano possui liberdade para tomar suas decisões e, pode conduzir sua existência na busca pela vita beata.

\section{CONCLUSÃO}

Não se procurou aprofundar se o ser humano possui liberdade realmente livre ou não, mas apenas elucidar que há em cada ser uma vontade e livre-arbítrio que fazem com que ele escolha entre o bem e o mal. A escolha pelo mal, por sua vez, é a tentativa de se equiparar ao seu Criador, o que consiste, para os crentes, no pecado original que levou à desordem toda a humanidade. A busca para ordenar, o que até então estava ordenado, baseia-se no caminhar em direção a sabedoria, por meio da boa vontade de cometer ações boas, estas darão à pessoa a recompensa de suas boas obras e, por consequência, adquirirá sabedoria, que tem por substância fundante a verdade, sendo esta o Sumo Bem. 
Pois bem, toda a pesquisa e hermenêutica realizada até aqui, permite ao leitor observar que a origem do mal consiste em um paradoxo, que inúmeros autores dedicaram a vida na tentativa de desenvolvê-lo. A questão da origem do mal como sendo a vontade é obtida por meio do desenvolvimento de uma análise profunda do ser humano e de sua natureza. Nesse trabalho, constata-se a procura por resolver algumas problemáticas do surgimento e natureza do mal para fundamentar o conhecimento do ser humano quanto a sua própria natureza e averiguar a dimensão transcendental da voluntas.

Chega-se à conclusão de que a vontade livre é a causa do mal. Assim, a vontade não basta por si, precisa ser boa e, isso, acaba por determinar a causa das boas e más ações do homem. A bona voluntas, por ser causa sui, não parte de nenhuma motivação externa que a condicione a cometer erros ou, até mesmo, fazer boas ações. Pelo contrário, por ser causa sua, possui vontade livre e determinante para decidir sobre uma ou outra coisa.

Porém, o ser humano não cai em um determinismo e, muito menos, se torna um ser menos livre por isso. Ele possui responsabilidade sobre seus atos e isso faz com que seja reinterpretada a história de cada sujeito e da sociedade. Pode-se questionar sobre as influências ambientais, familiares, psicológicas e sociais que podem condicionar a pessoa a agir de tal maneira. Isso, durante o processo de pesquisa, permaneceu presente e não se encontrou resposta, pois, como dito anteriormente, esse artigo não buscou desenvolver tais questionamentos.

Além disso, com a perspectiva judaico-cristã, é possível compreender o motivo que determinadas crenças religiosas, que exercem influência na sociedade, possuem tanto peso sobre as ações dos seres humanos determinando o seu agir. Tais crenças servem como instrumento para fundamentar as ações morais e éticas, conduzindo as pessoas a viverem com retitude buscando uma vita beata para alcançar a Veritas. Interessante como muitos, de maneira inconsciente, acabam submissos a certos conceitos morais e éticos que não foram buscados por si, mas que a forma como foram criados e inseridos no meio social os levou a certo tipo de condicionamento e aderência. 
Para além desses fatores externos, há uma medida interna existente no ser humano que o possibilita a viver secundum uma lex aeternam, que está presente na sua anima que movimenta e dá vida ao corpo e que liga o ser ao Transcendente. Esta ligação pode ser traduzida como participação da pessoa humana na pessoa divina. Tal participação conduz o ente humano a buscar o ente divino em um movimento crescente e dialógico. Assim, convergindo com a interpretação realizada sobre a origem do mal na Tradição Bíblica, há possibilidade de perceber a ligação entre o homem e seu Criador.

O norteador desse estudo foi a busca da compreensão da origem do mal numa determinada perspectiva filosófica e religiosa. A consequência de afirmar que há no ser humano uma vontade livre que é causa sua e que se autodetermina, é que o ser humano não consegue acertar em todas as suas ações. Ora acerta, ora erra. Como superar isto? Bem, a pessoa por mérito próprio pode ser incapaz, mas pode vir a ser virtuosa em suas ações volitivas se Deus a der a sua graça. Dado o exposto, o ser precisa recorrer ao seu Criador e pedir seu auxílio para superar este paradoxo interior de sua livre vontade.

Não se quer afirmar uma dependência do ser humano em relação a Deus. Pelo contrário, afirma-se que o ser humano tem a livre vontade de escolher entre o pedir a graça necessária para viver uma vita beata ou decidir permanecer autor de suas escolhas sem a ajuda de seu Criador. Esta escolha pode resultar em uma má vivência ou não de sua existência. A escolha, em ambas as situações, está em cada ser humano. Por isso, o Libero Arbitrio é um bem dado ao ser, para que ele, livremente, recorra ao seu Criador em um ato inteiramente livre e responsável.

Conclui-se, então, que cada pessoa, ao buscar sua felicidade, procura recobrar a integridade interior de criatura divina, que foi criada a imagem e semelhança de Deus, e aproximar-se dela. Porém, por suas próprias forças, pode acabar fracassando durante a busca e vir a desistir, pois o caminho à virtude requer viver com retidão, modéstia e desapego das coisas temporais e amar as eternas. Necessariamente, nessa perspectiva, o ser humano precisa pedir a graça divina para que consiga 
recobrar sua integridade originária, tornando-se, em algum momento e dentro das suas condições e possibilidades, um ser perfeito e ordenado.

Há, no decorrer desse estudo, a percepção de uma composição conceitual harmoniosa que resulta em um belo elogio a Sabedoria e a Verdade imutáveis. Isto se dá na declaração de que o ser humano, ao buscá-las, não perde sua vida, pelo contrário, a ganha, pois um dia sequer diante do Senhor vale mais do que milhares de anos longe dEle. Nobríssima motivação para todos, sem distinção, buscar uma vida virtuosa para algum dia alcançar a única e verdadeira Verdade que é o Summum Bonum.

O desejo que permanece é que, por meio desta pesquisa, o leitor possa compreender seu funcionamento interno e, com isso, utilizar-se de tão grande bem, que é a Bona Voluntas, para direcionar sua vida para um viver virtuoso. Favorecendo, assim, a possibilidade de um viver com sabedoria, usando a ratio para dominar o appetitus que conduz o ser ao erro. Isso possibilitará um viver reto, uma vida segundo a lei temporal que tem como fundamento a lei eterna. Portanto, o homem é conduzido ao conhecimento da Veritas, do Summum Bonum o que gerará uma vita beata, por meio de sua bona voluntas.

\section{REFERÊNCIAS}

AGOSTINHO, Santo. Confissões. 7. ed. São Paulo: Paulus editora, 2016.

AGOSTINHO, Santo. O Livre Arbítrio. 10. ed. São Paulo: Paulus editora, 2019.

ANSELMO, Santo. Livre arbítrio e predestinação: uma conciliação entre a presciência e a graça divina. São Paulo: Fonte Editorial, 2006.

ARMAS, Fr. Gregório, O. R. S. A.. Teologia augustinian del pecado. in: AVGVSTINVS, V. I, 1956.

BÍBLIA SAGRADA: versão de estudos. São Paulo: Ave Maria editora, 2019. 
BOÉCIO. Consolação da filosofia. São Paulo: Martins fontes, editora, 1998.

BRACHTENDORF, Johannes. Confissões de Agostinho. Trad. Milton Camargo Mota. São Paulo: Loyola, 2008.

BROWN, Peter. Santo Agostinho: uma bibliografia. Trad. Vera Ribeiro. Rio de Janeiro e São Paulo: Ed. Record, 2005.

CANTALAMESSA, Raniero. Apaixonado por Cristo: o segredo de Francisco de Assis. São Paulo: Fons Sapientiae editora, 2019.

CENTENO, Andrés. Obras completas de San Agustín: De I agracia de Jesus Cristo y del pecado original. Madrid: La editorial Católica/ BAC, 1956.

COSTA, Marcos Roberto Nunes. 0 problema do mal no início do pensamento de Agostinho. Porto Alegre: EDIPUCRS, 2002.

Dicionário Latim Português. Portugal: Porto editora, 2019.

GILSON, Etienne. Introdução ao estudo de Santo Agostinho. São Paulo: Discurso Editorial e Paulus, 2007.

GIRARD, Marc. Os símbolos na Bíblia. 2. ed. São Paulo: Paulus, 2005.

GUNNERWEG, Antonius H. J. Teologia bíblica do Antigo Testamento: Uma história da religião de Israel na perspectiva bíblico-teológica. São Paulo: Loyola, Teológica, 2005.

LA PEÑA, Juan Luiz Ruis. Criação, Graça, Salvação. São Paulo: Loyola, 1998.

LÓPEZ, Felix Garcia. O pentateuco: introdução a leitura dos cinco primeiros livros da Bíblia. São Paulo: Ave Maria, 2004.

MACHADO, Jorge. Os indícios de Deus no homem: uma abordagem a partir do método fenomenológico de Martin Heidegger. Porto Alegre: Edipucrs, 2006. 
MALDAMÉ, Jean-Michel. O pecado original: Fé cristã, mito e metafísica. São Paulo: Loyola, 2013.

MOSER, Antônio. O pecado: do descrédito ao aprofundamento. 4. ed. Petrópolis: Vozes, 1996.

NOVAES FILHOS, Moacyr Ayres. A razão em exercício: Estudos sobre a filosofia de Agostinho. São Paulo: Discurso Editorial, 2007.

Obras completas del Pseudo Dionisio Areopagita. Madrid: Biblioteca de autores cristianos, 1990.

$\mathrm{PICH}$, Roberto Hofmeister. Agostinho e a "descoberta" da vontade: primeiro estudo. Porto Alegre: Veritas, V. 50, n², 2005.

$\mathrm{PICH}$, Roberto Hofmeister. Agostinho e a "descoberta" da vontade: primeiro estudo (continuação e fim). Porto Alegre: Veritas, V.50, n`3, 2005.

$\mathrm{PICH}$, Roberto Hofmeister. Agostinho sobre justiça e paz. in Bravaresco, Agemir (ed), Filsoofia, Justiça e Direito. Pelotas: Educat, 2005.

$\mathrm{PICH}$, Roberto Hofmeister. Sobre a descoberta e a justificação da vontade: notas sobre o De Libero Arbitrio II. Civitas Avgvstiniana, 2, 2002.

PIETRO, Teófilo. Obras completas de San Agustín: De las costumbres de la Iglesia Católica y de las costumbres de los Maniqueos. 4. ed. Madrid: La Editoral Católica/ BAC, 1956.

PLATÃO. Protágoras. São Paulo: Edipro, 2012.

REIS, Émilien Vilas Boas. A faculdade da vontade na polêmica antipelagiana em Santo Agostinho. Porto Alegre: PUCRS/BCE, 2010.

REIS, Émilien Vilas Boas. O conceito de virtude no jovem agostinho: evolução ou revolução. Porto Alegre: PUCRS, 2006. 
RICOEUR, Paul. O mal: um desafio à filosofia e à teologia. Campinas: Papirus, 1988.

RUBIO, José. Introdución a la teología Del pecado em San Agustín. in. AVGVSTNVS. V. 09, 1964.

SILVA, Dayvid da. Pecado original: uma herança agostiniana? O tema da "falta das origens" e suas consequências. São Paulo: PUC-SP, 2015.

\section{APÊNDICE - REFERÊNCIAS DE NOTA DE RODAPÉ}

2. Pentateuco é como é chamado o conjunto dos cinco primeiros livros da Bíblia. Estes cinco livros também são denominados de "a Lei" ou "Torá". Os livros que compõe o Pentateuco são: Gênesis, Êxodo, Levítico, Números e Deuteronômio. A palavra Pentateuco vem do grego pentateuchos, que significa "livro de cinco volumes".

3. BÍBLIA SAGRADA: Versão de estudos. São Paulo: Ave Maria editora, 2019. p. 23.

4. O sentido de morte aqui abordado será elucidado ao longo do artigo.

5. Cf. BÍBLIA SAGRADA: Versão de estudos. pp. 24-25.

6. REIS, Émilien Vilas Boas. A faculdade da vontade na polêmica antipelagiana em Santo Agostinho. Porto Alegre: PUCRS/BCE, 2010. p. 20.: "[...] mesmo que se mostre como fazer o mal, em última instância, quem o faz é o indivíduo particular, que acata fazê-lo. [...] Nesse sentido, fica exposto que 0 ato exterior isoladamente não pode ser condenado. Alguém poderia querer cometer um ato mau e não poder concretizá-lo, por estar impedido de alguma forma. Antes do ato concreto exterior, praticado pelo homem, há algo no interior do ser humano que o possibilita proceder mal: a 'paixão' (“libido"), que Agostinho também denominará como um mau 'desejo' ou 'concupiscência' ("cupiditas")".

7. Cf. BÍBLIA SAGRADA: Versão de estudos. Ver notas explicativas referente ao capítulo 3 versículos 1-24. pp. 24-25. 
8. LÓPEZ, Felix Garcia. O pentateuco: introdução a leitura dos cinco primeiros livros da Bíblia. São Paulo: Ave Maria, 2004. p. 69.

9. Cf. REIS, Émilien Vilas Boas. p. 22.: "[...] Agostinho, para especificar se um ato é bom ou mau, volta-se para o que o homem deseja. Se o desejo for pelas coisas temporais, é um mau desejo; entretanto, se o desejo for pelas coisas não-perecíveis, o desejo é bom". O desejo, assim, move o homem a cometer determinada ação. Toma como matéria para definir se tal desejo é bom ou é mau o objeto desejado e as consequências desta escolha. Usando esta premissa agostiniana para ler e interpretar o pecado originário, constata-se que Eva cometera um ato mau, pois seu objeto de desejo era ser igual a Deus, conhecedora do bem e do mau.

10. Idem. p. 28.: "O homem pode conhecer plenamente uma situação que se mostra errada e, mesmo assim, optar por cometer o mal. [...] É, unicamente, pela vontade que o homem comete um ato mal. $\mathrm{O}$ autor do pecado é a própria vontade livre e, por ser autor do pecado, o homem deve pagar por tal equívoco". Para complementar essa ideia, vede nota $n^{\circ} 13$

11. Ibidem. p. 18-19, afirma: "O que estaria implícito na questão formulada por Evódio é: a) Só há um Deus; b) Ele é criador de todas as coisas; c) há o mal; logo, d) Deus seria o autor do mal.

Este raciocínio do parágrafo anterior está incompleto, pois, nas três primeiras premissas expostas, falta outra, que os cristãos também proclamam em relação a Deus: 'Deus é bom'. Deus não é o autor do mal. Como há o mal, é necessária uma análise pormenorizada sobre a origem do mal". Agostinho no De Lib. Arb. 1,1,1, faz, de certo modo, uma elucidação de que Deus não é o autor do mal e fala sobre a perturbação que o ser humano tem em sua alma: "Credimus autem ex uno Deo omnia esse quae sunt; et tamen non esse peccatorum auctorem Deum. Movet autem animum, si peccata ex his animabus sunt quas Deus creavit, illae autem animae ex Deo, quomodo non parvo intervalo peccata referantur in Deum." (Cremos em um Deus, que faz ser todas as coisas que existem, e, ainda, que Deus não é o autor do mal. Porém, perturba-nos a alma: se os pecados vem daquelas almas criadas por 
Deus, e, por outro lado, se as almas existem a partir de Deus, como não referenciar à Deus os pecados, dado a relação intrínseca entre pecado e alma?) tradução obtida cf. Émilien.

12. Cf. BÍBLIA SAGRADA: Versão de estudos. Ver notas explicativas referente ao capítulo 3 versículos 1-24. pp. 24-25.

13. CANTALAMESSA, Raniero. Apaixonado por Cristo, o segredo de Francisco de Assis. São Paulo: Fons Sapientiae, editora, 2019. p. 49. "Em todas as línguas pelas quais a Bíblia passou até chegar a nós, ou seja, em hebraico, em grego, em latim e em português, a palavra humildade tem dois significados fundamentais: um objetivo, que indica rebaixamento, pequenez ou miséria de fato, e um subjetivo, que indica o sentimento e o reconhecimento que se tem da própria pequenez".

14. Caso contrário a culpa pelo mal cometido não seria do ser humano, o que o inocentaria da culpa de seus atos. Essa perspectiva coincide com a visão maniqueísta do mal. Cf. REIS, Émilien Vilas Boas. p. 18. Afirma que: "Por 9 anos, período em que permaneceu ligado à seita maniqueísta, a visão dualista sobre a criação do mundo respondeu ao problema do mal à Agostinho. A lógica maniqueísta era a seguinte: a) O mal é um fato observado por todos; mas b) não se deve imputar a Deus o mal, logo, c) há um outro princípio que traz o mal. Assim, para os maniqueístas, o mundo é formado por dois coprincípios: um princípio da luz (Deus-Bem), e um princípio das trevas (Demônio-Mal). O que os maniqueus proporcionavam com esta visão era a total ausência de culpa do indivíduo sobre seu ato mau, pois, como tudo no universo, o homem também é formado por estes dois princípios".

15. De Lib. Arb. I, 6,15: "Quid? Illa lex quae summa ratio nominatur, cui semper obtemperandum est, et per quam mali miseram, boni beatam vitam merentur, per quam denique illa quam temporalem vocandam diximus, recte fertur, recteque mutatu, potestne cuipiam intellegenti non incommutabilis aeternaque vederi? Na potest aliquando insiniustum esse ut mali miseri, boni autem beati sint". (Quanto àquela lei, que é determinada suma razão, que sempre é obedecida, e pela qual aos maus é merecida a miséria, e os bons é merecido à vida feliz, e, pela qual, finalmente, 
dissemos que a (lei) chamada temporal, obtém retidão e modificações. Pode, quem possui inteligência, não ver se (a lei eterna) imutável e eterna? Ela pode alguma vez ser injusta, quando faz os maus miseráveis, ou quando torna os bons felizes?) Tradução cf. Émilien.

16. Cf. REIS, Émilien Vilas Boas. p. 28.: "Se para o pensamento helênico o homem peca por ceder a razão ante à paixão, por uma falta de entendimento de toda a situação, para Agostinho, a vontade 'descoberta', passa a ser a causa do mal".

17. PICH, Roberto Hofmeister. Agostinho sobre justiça e paz. in BRAVARESCO, Agemir (ed), Filosofia, Justiça e Direito. Pelotas: Educat, 2005. Alega que "De Libero Arbitrio é tanto a primeira análise da vontade e da escolha livre feita por Agostinho quanto a primeira obra da filosofia ocidental sobre a vontade no sentido fundamental em que é pensada hoje: como um poder cognitivo-desiderativo ativo de livre decisão, que se deixa definir por meio da autodeterminação e/ou do indeterminismo das ações, que, ademais, se diferencia da faculdade da razão e da faculdade do desejo."

18. Evódio em De Libero Arbitrio faz questionamentos a Agostinho que o leva a discorrer sobre a questão da originalidade do mal. A pergunta que merece destaque é "Dic mihi, quaeso te, utrum Deus non sit auctor mali? A partir disso, é possível perceber por quais veredas a obra escrita pelo Santo será conduzida. Segundo o Dr. Prof. Roberto Pich em aula ministrada no curso de filosofia na PUCRS, a prova de que Deus não é o autor do mal e que o livre-arbítrio é um bem e não um mal, isto consiste em assuntos norteadores para Agostinho escrever sua obra.

19. Cf. REIS, Émilien Vilas Boas. p. 25-26.: "O homem também pode buscar o amor ao elogio, a glória e o desejo de dominar. Todas estas coisas são denominadas apetites ("appetitus"). Assim, o homem pode ter duas posturas na realidade: ou sua 'ratio', a melhor parte do homem, domina os 'appetitus', ou os 'appetitus' subordinam a 'ratio'. Estar ordenado é justamente 'dar a cada um o que é seu', como clamou a tradição ocidental desde os helênicos. Agostinho interpreta, neste caso, o 'dar a cada um o que é seu' como subjugar a pior parte à melhor parte, isto é, o mais forte deve dominar o mais fraco. $O$ homem ordenado é o homem que se guia pela razão. E, por 
sua vez, levar vida ordenada é algo que se fundamenta na própria lei eterna. Este homem ordenado é o sábio ("sapiens"), figura exemplar do pensamento antigo, que será assimilada por nosso pensador".

20. BOÉCIO. Consolação da Filosofia. São Paulo: Martins Fontes, Editora, 1998. p. 151.

21. PICH, Roberto Hofmeister. Agostinho e a "descoberta" da vontade: primeiro estudo. Porto Alegre: Veritas, 2005. p. 140.

22. Cf. REIS, Émilien Vilas Boas. p. 23.: "As leis humanas têm por característica serem úteis às sociedades das quais se originam. Essas leis, feitas por homens, são mutáveis e sujeitas ao tempo, tal qual é o homem; o que explica a diversidade de leis positivas. Estas leis não têm os seus fundamentos nas sociedades temporais. É preciso buscar o fundamento fora delas. Este fundamento é a lei eterna ("lex aeterna"). Será a partir da análise desta lei, que descobriremos como a vontade humana é responsável, em última instância, pelos atos humanos. Uma lei temporal ("lex temporale") só será justa se tiver como fundamento a lei eterna".

23. AGOSTINHO, Santo. O Livre Arbítrio. São Paulo: Paulus Editora, 2019. p. 35.

24. LATIM PORTUGUÊS, Dicionário. Portugal: Porto Editora, 2002. Tradução nossa: Livre Arbítrio e Vontade. Como o livro no qual está sendo baseado esse estudo foi escrito originalmente na língua latina, optou-se por utilizar os termos latinos para buscar expressar com mais clareza o contexto linguístico que o autor vivera e sua etimologia. Ao fazer a citação em latim, expunha e aproxima, de certa maneira, o leitor com a obra originária.

25. PICH, Roberto Hofmeister. Sobre a descoberta e a justificação da vontade: notas sobre o De Libero Arbitrio II. CIVITAS AVGVSTINIANA, 2, 2012. pp. 163- 164.: "É, ao que tudo indica, a primeira obra em absoluto da filosofia ocidental sobre a vontade no sentido fundamental em que é pensada ainda hoje: como um poder cognitivodesiderativo ativo de livre decisão, que se deixa definir por meio da autodeterminação e/ou pelo indeterminismo das ações, que além disso, se diferencia claramente da 
faculdade da razão e da faculdade do desejo. [...] Daí se entende que a tese do Livro I reside em que a vontade livre é a causa do mal". Ou seja, a vontade por ser causa sui pode tender tanto para a boa ação quanto para a má ação, isso, claro, ao se autodeterminar e tomar-se como objeto. A boa vontade depende apenas da sua própria vontade para realizar determinada ação, é livre e não precisa de motivações externas, apenas a si própria.

26. PICH, Roberto Hofmeister. Agostinho e a "descoberta" da vontade: primeiro estudo. Porto Alegre: Veritas, 2005. p. 140.

27. Cf. AGOSTINHO, Santo. O Livre Arbítrio. p. .50.

28. Cf. ÉMILEN V. B. Reis. p. 27.: "[...] há os homens sábios que são ordenados, cuja razão domina os 'appetitus'; por outro lado, há aqueles que não são ordenados, cujas partes inferiores subjugam a razão, estes são denominados estultos ("stultos")". Assim, a autora elucida de forma objetiva o paradoxo apontado. Levanta-se a questão do porquê um é sábio e ordenado e outro é estulto e desordenado, sendo eles criaturas divinas? Essa dúvida continuará presente durante esta obra e, talvez, será apontado alguns caminhos para construir uma conclusão desta problemática entre "ratio et appetitus".

29. Idem. p. 26.: "[...] Agostinho falara sobre a figura do sábio. Na obra Contra Acadêmicos o homem excelente será mostrado como aquele que vive com sua melhor parte, chamada 'mens' ou 'ratio', dominando as demais. Este homem será denominado feliz por buscar e encontrar a verdade ("veritas"), claramente, numa contraposição à figura cética, que julga o homem não poder encontrar a verdade. Nessa mesma obra, o sábio será também identificado como aquele que possui a sabedoria ("sapientia")."

30. No presente estudo não se propõe aprofundar a problemática da liberdade do ser humano, se existe ou não e em quais circunstâncias o ser humano é livre. Apenas aponta, por meio da pesquisa realizada em Santo Agostinho, as afirmações feitas pelo autor com relação a determinado assunto. 
31. Cf. ÉMILEN V. B. Reis. p. 30.: "Assim, como todos os assentimentos dos indivíduos passam pela vontade, o querer ser feliz também depende da vontade. Todo ato desiderativo depende da vontade, tal como o ato desiderativo de se possuir uma boa vontade ("bona voluntas"). Agostinho, abruptamente, passa a falar da boa vontade em relação à felicidade. Esta mudança poderia aparecer estranha se não soubéssemos que Agostinho igualará o homem feliz ao homem de boa vontade. Em que consiste a boa vontade? 'É a vontade pela qual desejamos viver de modo reto e honestamente, e pela qual atingimos a suma sabedoria'. Ainda sem explicitar completamente o que seja a boa vontade, Agostinho, de certa maneira, nos oferece algumas características: a) é uma vontade; de b) viver com retidão e honestidade, que c) nos oferece a suprema sabedoria". Aqui é elucidado de forma detalhada o que Agostinho deseja determinar por bona voluntas que conduz o homem à felicidade.

32. Cf. REIS, Émilien Vilas Boas. p. 19.: "Além de ser bom (não praticar o mal), Deus também é justo, dá a cada um o que lhe é devido; recompensas aos bons e castigos aos maus. E como cada um só pode ser julgado por Deus a partir de sua própria ação, [...] não é, pois, um só alguém (autor do mal), mas cada malvado é o autor de suas más ações [...] Pois, não seriam punidos justamente, a não ser que viessem (as más ações) da vontade".

33. Cf. Bíblia Sagrada: Versão de estudos. p. 26.

34. LATIM PORTUGUÊS, Dicionário. Portugal: Porto Editora, 2002. Tradução nossa: Virtude e Felicidade.

35. MACHADO, Jorge. Os Indícios de Deus no Homem: Uma abordagem a partir do método fenomenológico de Martin Heidegger. Porto Alegre: EDIPUCRS, 2006. p. 102 -103.: "A vida feliz já foi um problema para o início da filosofia, e então chega na confrontação do cristianismo de Agostinho com a filosofia grega, especialmente o estoicismo, a partir do qual ele providencia seu argumento para a vida feliz, tanto quanto de sua existência no momento: todo mundo quer uma vida feliz. Mas eu não posso amá-la se eu não conhecer nada sobre a vida feliz." - aqui está o ponto crucial para compreender o conceito de felicidade agostiniana que possui uma visão 
neoplatônica- "Mas eu não posso amá-la se eu não conhecer nada sobre a vida feliz. Por esta razão, a vida feliz deve já estar presente na memória. Mas como? Não como eu lembro de algum objeto dos sentidos, '[...] a felicidade não se vê com os olhos, pois não é corporal, nem com os números, pois quem quer conhecer os números não deseja adquiri-los[...], enquanto nós somos inclinados a amar e querer possuir uma vida feliz' (cap. XXI); Nem como forma de eloquência, que eu tenho observado nos outros e com quem poderia aprender. Mas a vida feliz não pode ser apreendida de outros, por nenhum sentido corporal. Não, a vida feliz é encontrada em mim mesmo, como uma tendência da alma que age para isso e se dirige para isso. Isto é, como uma alegria que percebo da mesma forma que percebo a tristeza. Mas nem todo prazer tem relação com a vida feliz. Ainda que todos os seres humanos desejem a vida feliz, eles não a querem com a intensidade suficiente para que eles se tornem capazes de alcançá-la, e então possam decidir por um direcionamento correto (cap. XXIII). A vida feliz deve ser trazida pela vontade intensa que é capaz de me colocar em direção a vita beata', posição em direção a mim', uma 'objetividade' (Gegenständlichkeit) que eu mesmo primeiro cultivo e modelo. A vida feliz baseia-se no modelo de uma vontade forte e desejo intenso".

36. Cf. AGOSTINHO, Santo. O Livre Arbítrio. p.62.

37. Cf. MACHADO, Jorge. p.104.: "Com o conceito de vida feliz como 'gozo da verdade', Agostinho justapõe dois pontos: preferes encontrar o gozo na verdade ou no erro? Mas esses dois pontos se sustentam na medida que surgem do interesse (Bekümmerung) para a verdade. É apenas a 'fraqueza' (tenuiter), que me leva para o gozo do erro. Na vida fática cada um vislumbra algo justo e valioso e vive na busca disso, desde o momento em que reconhece sua importância. E assim, pode resistir à decisão de ir ao encontro da vita beata, pois encontra essa dificuldade em reconhecêla e se convencer a si mesmo. Ama a verdade confortável, mas ao ser questionado angustia-se e fecha os olhos. 'Ele ama a verdade quando ela é agradável; ele odeia a verdade quando ela censura, quando põe em questão sua existência fática' (cap. XXIII)."

38. Cf. AGOSTINHO, Santo. O livre arbítrio. p. 62. 
39. Summum Bonum em tradução própria e literal significa Sumo Bem. Terminologia bastante utilizada por Agostinho em De Libero Arbitrio.

40. Cf. MACHADO, Jorge. p. 106.: "Deus responde em nossa consciência e vê nosso interesse e nossos objetivos. Ele observa nosso coração e vê nossa consciência. Ele examina os 'quadris' do mesmo modo que vê o objetivo do coração, que é feliz. Abruptamente, Deus investiga o que nós secretamente desejamos".

41. Conceituação estudada na matéria de Metafísica I ministrada pelo Dr. Prof. Sérgio Augusto Sardi no segundo semestre de 2019.

42. Cf. MACHADO, Jorge. p. 100.

43. Cf. REIS, Émilien Vilas Boas p. 34.: "Em suma, é esta ordem universal que coloca o homem em uma determinada posição dentro do universo criado; é o que garante à interioridade humana papel fundamental nas ações humanas. Através desta ordem, o homem não pode ser subjugado por nada exterior a ele, se ele estiver ordenado".

44. Cf. MACHADO, Jorge. p. 103.: "Se a vida feliz é uma experiência, então ela nunca pode ser procurada ou encontrada no mundo. Ela não é um objeto (objekt) e não pode ser apropriada de outros. A realização da vida é sempre uma realização própria, tanto que a experiência individual é sempre ativamente envolvida nela". - A conceituação de vida feliz aqui abordada faz referência a felicidade que o ser humano busca. Importante notar que o autor afirma que a felicidade é uma experiência que não é encontrada fora de si ou vivenciada por outros, cada pessoa é responsável pela busca pela felicidade, ou na terminologia do autor, pela vida feliz. Ele continua afirmando- "A questão do 'como' eu tenho uma vida feliz também já produz uma resposta do que ela é. Acontece na delectatio. Mas a despeito dessa prefiguração de um sentido específico do que é a vida feliz, deve também ser notado que o fenômeno da delectare aqui, e de forma geral, nunca é esclarecido por Agostinho. Segundo Heidegger, Delectatio assume diferentes sentidos: 1) o gozo como relação 2) sobre o que eu gozo (conteúdo) 3) o gozo em sua atualização 4) o gozo como fenômeno ao qual Agostinho alude". - o como se dá a vida feliz ou felicidade diz como ela é. O autor afirma que, 
segundo Heidegger, Agostinho compreende a felicidade como um gozo do fenômeno, ou seja, quando se experiencia a verdade sente o deleite de estar a possuir aquilo que dá sentido a vida humana. Sendo assim, como já afirmado, Agostinho é Cristão Católico, e como tal, acredita em uma única Verdade que é Cristo, portanto, a vida feliz, ou felicidade, se dá quando a criatura está em contato com a Verdade, que é Cristo, experimentando estado de gozo.

45. Idem. p. 102.: Além dessa citação onde o autor procura elucidar o peregrinar do ser humano exposto por Agostinho, ele continua afirmando que: "Ele (Agostinho) quer definir como a vida feliz, e a busca desta é psiquicamente viva, e distingue dois modos de procurá-la: pela lembrança ou 'pelo desejo de aprender' (per appetitum discendi). O segundo modo ameaça 'suspender' a clássica tese da anamnese, isto é, que aprender é sempre recordar.". Ou seja, ele traz à luz a antiga problemática entre a reminiscência de Platão, onde o ser não obtém conhecimento novo, tudo é recordado e o desejo de aprender, pois se o ser humano pode aprender ele não obteve em algum momento de sua existência o conhecimento de tudo, que anula o processo de reminiscência. Adiante o autor conceitua o que é o conceito de felicidade agostiniana.

46. Cf. MACHADO, Jorge. p. 104.: "Agostinho esclarece em que o sentido da vida feliz é deleite quando ele condiciona que é um 'gozo da verdade' (gaudium de veritate) (cap. XXIII). Este conceito de verdade está fora de sua avaliação da filosofia de seu tempo, especialmente do neoplatonismo. A verdade que reside na vida feliz tem um sentido moral básico diferente da verdade da asserção teórica. Mas age sobre a vida religiosa de Agostinho. Assim, pode insinuar a relação do senso teológico de Cristo como a Verdade. Enraíza a questão sobre em que implica realmente a verdade filosófica."

47. Cf. AGOSTINHO, Santo. O livre arbítrio p. 107.

48. Cf. PICH, Roberto Hofmeister. p. 194, nota 97.: "A lei eterna, aqui, é metafísica nos seguintes termos: é o conhecimento da própria interioridade, do sentido da ordem que realiza a própria natureza, que é adequada, racional e preservadora do ser humano senhor de si, em conhecimento e liberdade. Daí ser ela uma lei sobre as 
motivações das ações, segundo a qual somente uma motivação que começa na liberdade estrutural da vontade-razão pode gerar ações moralmente boas e desenvolver virtude. Deste modo, se o si mesmo é preservado, a ação será moralmente legítima".

49. Cf. MACHADO, Jorge. p. 105.: "Para essa dádiva, Deus é 'abstinência feliz', o esforço poderoso de contentamento. 'A continência reúne os elementos de nossa pessoa, reconduz-nos à unidade que perdemos, dispersando-nos por tantas criaturas. Pouco Te ama quem Te ama juntamente como algo, e não ama por tua causa' (cap. XIX)."

50. Obras Completas del Pseudo Dionisio Areopagita. Madrid: Biblioteca de Autores Cristianos, 1990. pp. 269 - 270.: "Por eso, como norma general, nadie se atreverá hablar de la Deidad supraesencial y secreta em términos o ideas que no hayan sido divinamente revelados em las Sagradas Escrituras. Efectivamente, cualquier palabra o concepto resultan inadecuados para expresar lo desconocido de la supraesencia, que está muy por encima de todo ser. Necesitamos, para esto, un conocimiento supraesencial".

51. Cf. MACHADO, Jorge. p. 105.: "Ainda que o contexto seja cristão, desde Agostinho, os temas da vida fática especialmente como alienação de Deus e luta em direção a Ele, ainda levam a um sentido formal que não é especificamente cristão. Assim, crença é aceitação confiante, esperança de uma abertura, e amor, uma devoção passiva (Hingabe) do eu. O capítulo XVIII conduz à raiz da esperança apenas porque esta é temperada em toda a parte pela alegria de Deus. 'Só na Tua misericórdia coloco toda a minha esperança' (cap. XXIX)."

Enviado: Março, 2020.

Aprovado: Maio, 2020. 